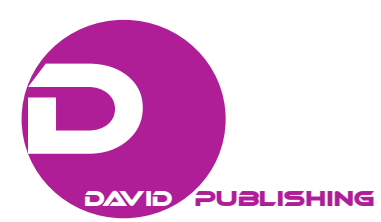

\title{
Business Service Centres and Their Current Challenges in Slovak Republic
}

\author{
Jarmila Hudáková \\ Constantine the Philosopher University in Nitra, Nitra, Slovak Republic
}

\begin{abstract}
Globalization of the world economy and the entrance of the information society have a significant impact on the development of business activities of individual firms. Since centralization and outsourcing of business services is a globally growing trend, this industry has enormous potential. Business Service Centres (BSCs) are considered to be a model in the European Union that leads to improved performance and results achieved by the company. Within the framework of EU free trade, up to $70 \%$ of European centres state that standardization and process transformation is the first corner in deciding to set up the BSC. The aim of the article is to analyse the market of business service centres in the Slovak Republic and their impact on employment within the EU. The competitive advantage of Slovakia lies above all in economic and political stability, geographic location, skilled workforce and European currency. Thanks to positive business experiences in Slovakia, most investors remain and large numbers of them are expanding their activities, despite the rising cost of work. Based on the use of quantitative methods, we analyse secondary data on business service centres. Higher education graduates are often the main source of workforce for business service centres.
\end{abstract}

Keywords: Business Service Centre (BSC), Shared Service Centre (SSC), Business Process Outsourcing (BPO)

\section{Introduction}

Trade liberalisation within the European Union and globalisation of the world economy together with easier access to foreign markets lead companies to enhance the efficiency of their management activities and centralise the processes. This led in the 1980s of the last century to the establishment of the first business service centres. The first Business Service Centre outside its region was opened by IBM in India in 1998.

The Business Service Centres (BSCs) are defined as branches of foreign or domestic companies performing services for their mother and sister companies, and/or for third parties. Most commonly it concerns the area of finances, IT services, customer services, purchase, human resource support, sales, and others (Skorková \& Tarišková, 2017). Depending on who the client of BSC is, we distinguish the following BSCs:

- Shared Service Centres - they perform specific in-house processes and hereby provide support to mother and sister organisations.

- Centres of Business Process Outsourcing - these companies provide services in the field of company

Jarmila Hudáková, Ph.D., MBA, assistant professor, Faculty of Natural Sciences, Institute of Economics and Management, Constantine the Philosopher University in Nitra, Nitra, Slovak Republic.

Correspondence concerning this article should be addressed to Jarmila Hudáková, Faculty of Natural Sciences, Institute of Economics and Management, Constantine the Philosopher University in Nitra, Tr. Andreja Hlinku 1, Nitra 94974, Slovak Republic. 
processes for third parties.

From the aspect of functioning, these two types are very similar-both cases centralisation of the in-house processes take place, aimed at their standardisation and increase of efficiency. The basic difference from the aspect of employees is that while in the Shared Service Centres each of the activities are directly performed by the employees of the given company, in centres for external service provision the employees perform these activities for their client - a third party.

Kislingerová (2008) defines the Shared Service Centre as a special unit, an internal outsourcing centre, which takes over the joint activities from other branches, and/or companies within the group or region, with the aim to optimise and formalise the process of their solving. Andrišin (2015) sees the Shared Service Centre as a specialised company branch that assumes and performs additional operating activities in order to achieve their standardisation, simplification, higher efficiency and lower costs.

According to Bergeron (2002) shared services is a collaborative strategy in which a subset of existing business functions are concentrated in a new, semiautonomous, business unit that has a management structure designed to promote; efficiency, value generation, cost savings and improved service for internal customers of the parent corporation, like a business competing in the open market.

Tammel (2017) points out the importance of the BSC in reducing the costs of the parent company and the affiliated companies. Since centralisation and outsourcing of corporate services is a globally growing trend, this sector has an enormous potential. Recently the model of these activities has been changing within the European Union. In the past, the main motive for providing such services was exclusively cost reduction. However, lately a new model has been formed leading to improved efficiency and results achieved by the company. Process standardisation and transformation take the first place when making a decision on opening a BSC. The cost reduction factor seems to come only on the second place.

Rothwell, Herber, and Seal (2011) join BSC with professional employability and professional carriers. On an example, he says that companies are setting up a BSC among other things, where there are enough workers with professional qualification.

Maatman and Meijering (2017) have shown that the consolidated dynamic capabilities of a BSC are also positively related to service value through improving its operational capabilities. Using of formal control mechanisms by the business units positively contributes to shared service value through their capacity to institute the use of informal control mechanisms.

Slusarczyk (2017) states the multitasking is also the characteristic feature of these centres - in the majority of entities the processes connected with more than one area are realised. It causes that the units that are located in the central Europe are able to provide services for their clients in a more complex manner.

Central Europe is European sub-region with a non-accurate demarcation geographical, and geopolitical. There is some construction historical affected the specific distribution of political power. Centre of Europe forms are logically buffer belt between the western and eastern parts of Europe, in the geographical context, between the west and the east in political and institutional terms. Also, the economic characteristics of the Central European countries were and are still some transition between the western prosperity and eastern poverty by mainly contrast in the performance of the economies, labour productivity, and qualification structure of the labour force. The Region of Central Europe is defined flexible depending not only on the geographical affiliation, but often they are rather historical reminiscences, institutional, political, and economic parameters 
connecting the different states of this part of Europe (Kučerová, 2016).

\section{Problem Formulation and Methodology}

The aim of the article is to analyse the market of Business Service Centres in the Slovak Republic and their impact on employment. Based on using quantitative methods in the article, we analyse the secondary BSC data in Slovakia from the aspect of their number, structure, and number of employees. At the end, we would like to draw attention to the benefits of BSC for the economy of the Slovak Republic.

\section{Business Service Centres in Region V4}

Countries V4 or the Visegrád Group, also called the Visegrád Four, is an alliance of four Central European states - Czech Republic, Hungary, Poland, and Slovak Republic - for the purposes of furthering their European integration as well as advancing their military, economic, and energy cooperation with one another. It originated in a summit meeting of the heads of state or government of Czechoslovakia, Hungary, and Poland held in the Hungarian castle town of Visegrád on 15 February, 1991. The Czech Republic and Slovak Republic became members after the dissolution of Czechoslovakia in 1993. The name of the Visegrád Group is derived, and the place of meeting selected, from a meeting of the Bohemian, Polish, and Hungaro-Croatian rulers in Visegrád in 1335.

Among European countries, countries like Ireland, Poland, Czech Republic, and Slovakia are attractive for BSCs. The Czech Republic is immediately after Poland the second biggest market for BSCs in the region of Central and Eastern Europe (Figure 1).

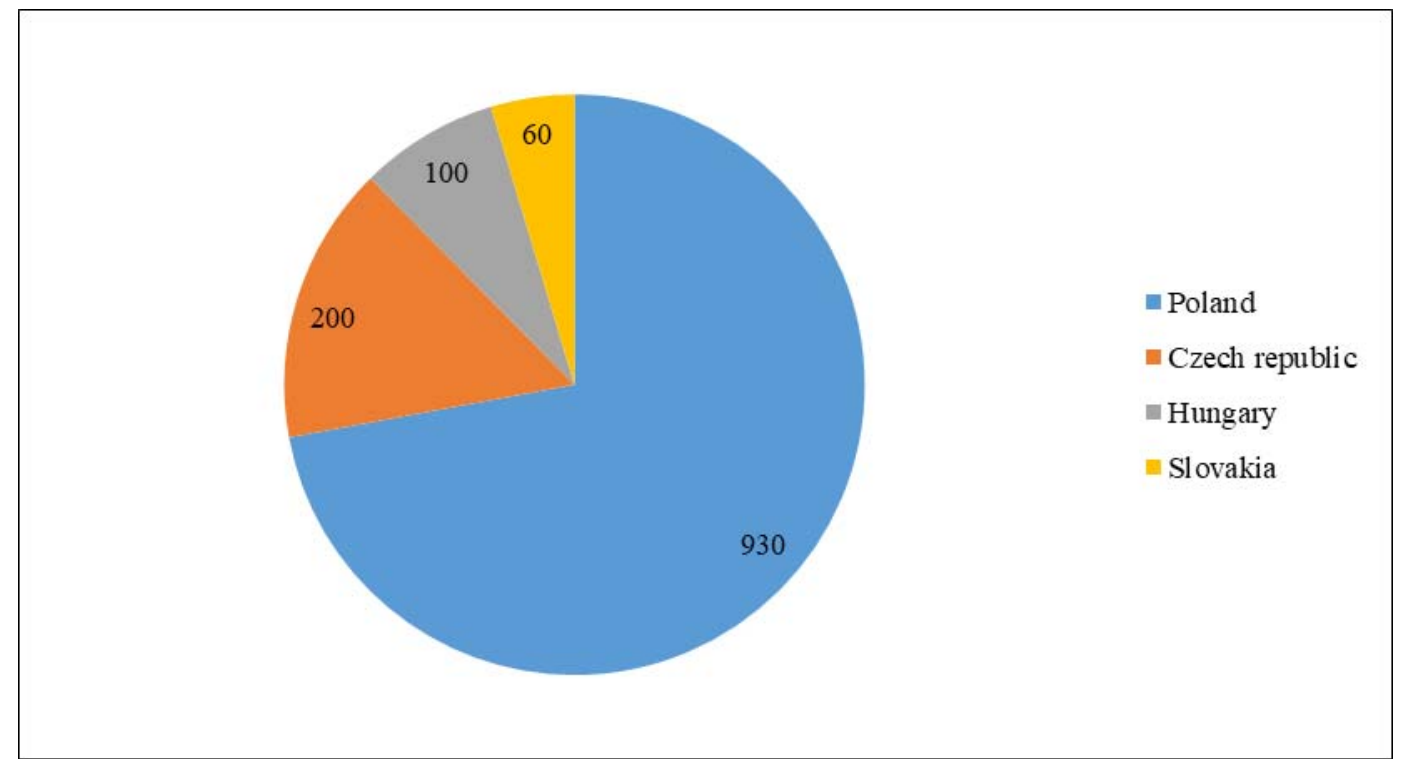

Figure 1. BSC number in V4 countries. Source: Grafton recruitment, own elaboration.

The advantage of these countries is not only their geographical position but also concentration of educated and multilingual employees. Figure 2 shows the number of employees in BSCs in V4. The most centres with the highest number of employees were established in Poland, which may be related to the lowest wage costs. 


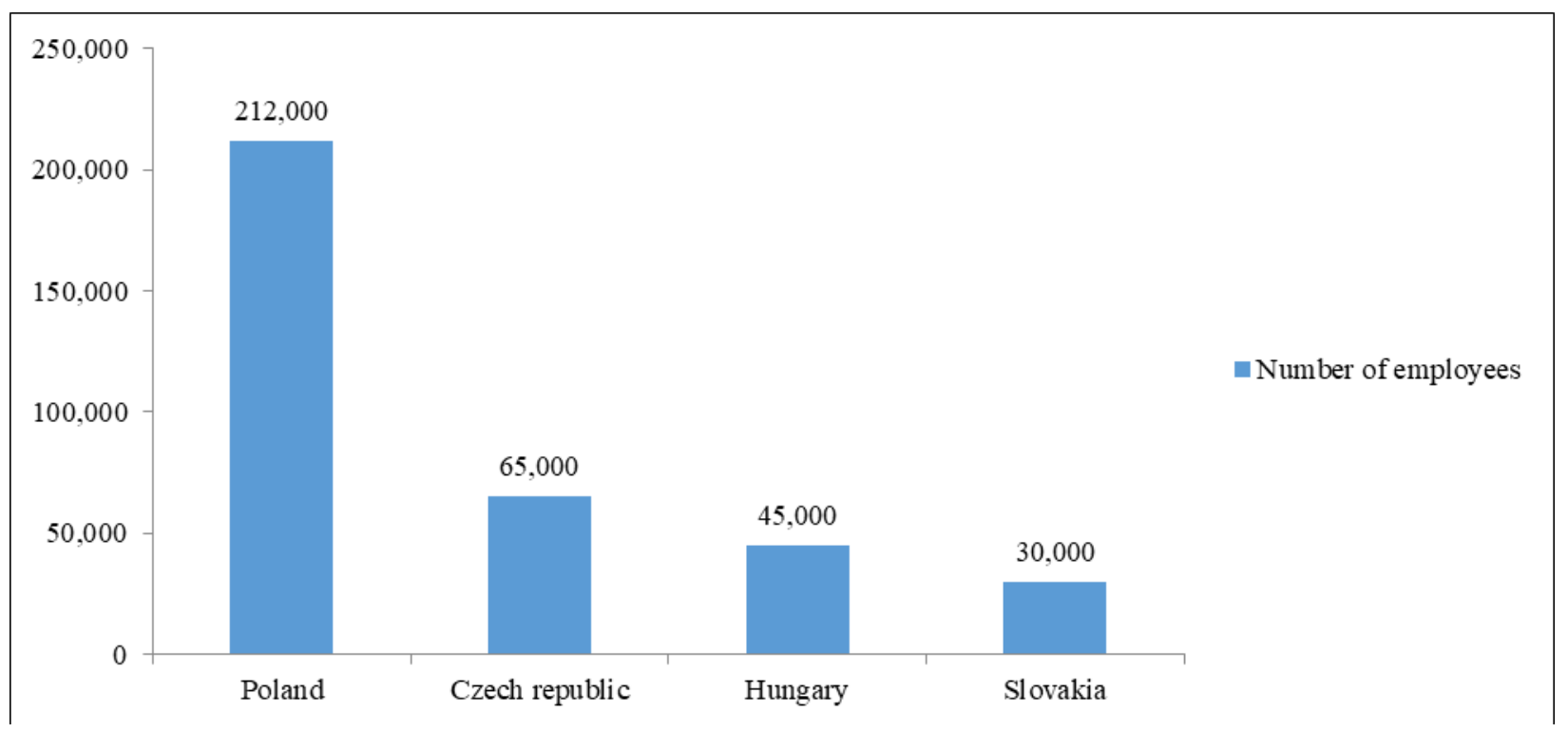

Figure 2. Number of employees in BSC. Source: Grafton recruitment, own elaboration.

Table 1 shows us the total costs of labour in a position with a salary of EUR 1,000. The best position from the V4 countries has Poland with salary cost only $22 \%$. Second position belongs to Hungary with salary cost higher by $6.5 \%$ than in Poland, follow Slovakia $33.0 \%$ and Czech Republic 34.0\%.

Table 1

Total Cost of Labour for Positions With a Salary of 1,000€

\begin{tabular}{lll}
\hline Country & Salary cost in \% & Cost of labour \\
\hline Poland & 22.0 & 1,220 \\
Czech republic & 34.0 & 1,340 \\
Hungary & 28.5 & 1,285 \\
Slovakia & 33.0 & 1,330 \\
\hline
\end{tabular}

Source: Own elaboration.

V4 countries, which lie at the middle of Europe, have become the most attractive destinations for many business subjects thanks to its advantageous geographic location, foreign investment incentives, and transport infrastructure. Language skills are a competitive advantage for all job seeker. Business Service Centres request candidates for job with various language combinations; English is considered a matter of course.

\section{Business Service Centre in Slovakia}

Nowadays multinational corporations already form an inseparable part of the Slovak economy. Apart from the direct impact on employment and GDP, foreign companies also indirectly develop the Slovak economy. A large number of small and medium enterprises are connected to these companies. Another positive externality is that foreign investors act as role models of business options in Slovakia for other companies from their home country. The competitive advantage of Slovakia consists mainly in economic and political stability, geographical location, qualified labour, and common European currency.

An important part of foreign direct investments in Slovakia is represented by BSCs. They are branches of foreign or Slovak companies performing in-house services for their mothers and sister companies, or for third 
parties in different areas. The most common areas include finances, IT services, customer services, human resource support, purchase, sale, and others. In the future, we can probably expect an increase in these activities, mainly in the field of cybersecurity, logistics, banking and insurance processes, and others.

The majority of BSCs is based on young, educated and linguistically competent labour that Slovakia has owing to its 35 higher education establishments. As shown by survey conducted by the Grafton recruitment agency, the most wanted candidates are graduates from economic and language faculties, since the most of the job positions are part of providing support to the branches abroad.

The wide network of higher education establishments in Slovakia is a part of the European area of higher education. We have 35 higher education establishments in Slovakia, out of that 20 public ones, three state ones, and 12 private ones. Higher education establishments in Slovakia offer professional studies in the following areas:

- Economy, management and law;

- Human and social sciences;

- Technology;

- Health care and veterinary education;

- Agriculture;

- Culture and art;

- Catholic school;

- Safety, policy force.

Figure 3 shows the number of students according to field of study. The most students study human and social sciences, followed by technical education, economy, management, law, and others.

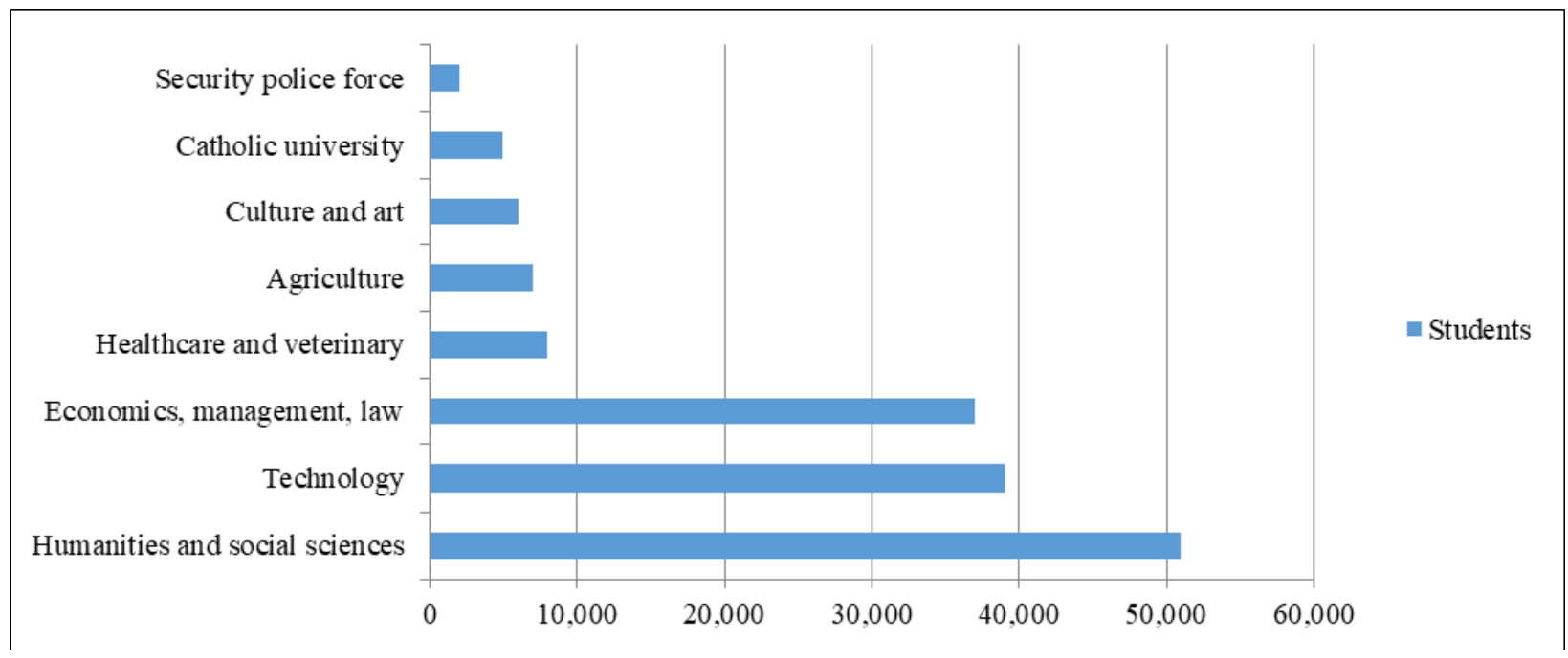

Figure 3. Number of students according to field of study. Source: portalvs.sk.

At the moment, BSCs in Slovakia grow at a rate of $70 \%$ to $80 \%$ representing the growth of the already existing centres, and the remaining 20\% represent newly established BSCs. More than 30,000 people are employed at business centres. The distribution of BSC market in Slovakia is not proportional (Figure 4) even if for the past few years the appetite of investors to establish their business centres also in other regions of Slovakia not only in the capital has been on the rise. About 78\% of all BSC employees work in Bratislava. 
There are only five BSCs in the Eastern Slovakia region but from the number of employees working there, it represents $17 \%$. When compared with a study from 2014 , the number of employees increased in the sector by 5,000 representing an approximate $10 \%$ year-to-year growth.

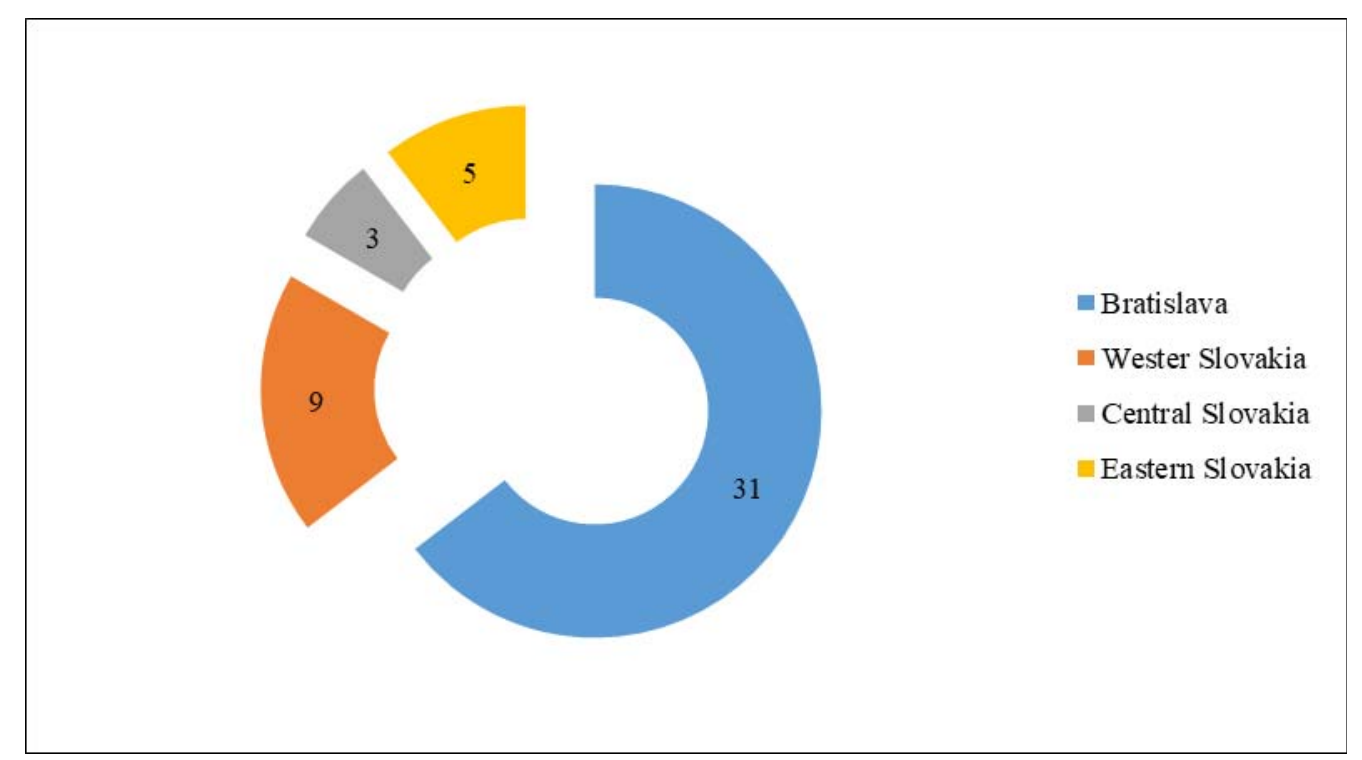

Figure 4. Number of BSCs in regions of Slovakia. Source: Grafton, own elaboration.

Based on the survey conducted by the Business Service Centre Forum (BSCF), more than $76 \%$ of BSC employees have university education and more than $95 \%$ of them use English or German at work. Other languages, such as Italian, French, Spanish, Dutch, and Hungarian are also used. About $90 \%$ of the BSC employees are citizens of the Slovak Republic, which is in contrast with the Czech Republic, where in some BSCs more than $60 \%$ of the employees are foreigners. The average age of employees is 32 years. From the gender perspective, the BSC sector has a balanced structure (46\% women) and at the same time also enables women to hold managerial positions ( $41 \%$ are women), as well as find employment in technical fields. Flexible employment forms highly contribute to the balanced gender structure.

As presented by the results of the survey conducted by the Grafton recruitment agency, the wages at BSCs rank, depending on the region and the job position, from EUR 700 (specialist of telesales in Prešov) up to a BSC director from EUR 4,000 to EUR 10,000. Customer services have the highest share in the activities of the Slovak BSCs. In this field, the salaries and wages rank from at least EUR 650 in Back Office specialist position in Žilina up to a maximum of EUR 1,200 in Bratislava. The salary in the Customer Operations Manager position starts from the minimum of EUR 1,500 in Žilina up to a maximum of EUR 3,200 in Bratislava. The average salary in BSCs achieves almost the double of the average salary in Slovakia.

BSCs are evidently very attractive not only for graduates, but also experienced workers, who would like to use their professional and language skills and acquire experience within an international environment. Grafton's survey shows that $68 \%$ job seekers speak English, up to 17\% English and German, 8\% of seekers speak English and French, 7\% English and Spanish, 6\% English and Italian, while 2\% of the total number of seekers speak a combination of English and Russian. Except English an additional European language at fluent level is frequently expected by BSCs. The most desirable are German, French, Italian, and Dutch. Up to $46 \%$ of job applicants speak at least one foreign language at level B2, with 18\% achieving level B1 language skills, 
which is enough to manage in-house communication or instruction in English. However, it is quite alarming that there is data declaring that only $4 \%$ of candidates speak a foreign language at fluent level $\mathrm{C} 2$.

\section{The Biggest Benefits of BSC for the Slovak Economy}

The main benefits of Business Service Centres include:

- Increase of stability and added value of the existing foreign investments;

- Support of non-industrial economy with a higher added value;

- Increase of professional employment in the regions;

- Employment of young people, efficient re-qualification of graduates and continuous education of employees;

- An alternative to working abroad.

On the other hand, BSCs currently start to struggle with increasing unavailability of free workforce with suitable soft and hard skills, high quality language skills, and different language combinations. The lack of suitable workforce is also related to the fluctuation of employees and with the problem to maintain them.

\section{Conclusion}

BSCs represent a significant part of the Slovak economy. The Slovak Republic supports the position of BSCs. Currently there are already two forms of aid that they can exploit and that is investment aid and programmes for foreign investor support. One of the main reasons why BSCs come to Slovakia is the qualified workforce. With the increasing number of BSCs and the increasing competition in the region of Central and Eastern Europe, as well as on the global scale, it is necessary to ensure to maintain this competitive advantage and take appropriate measures. It is essential to align the labour market with the supply and contents of school subjects - to put emphasis on teaching business, digital and soft skills at all levels of the educational system.

\section{References}

Andrišin, P. (2015). Business service centres-What you have (perhaps) not heard yet. Zisk Management, II, 18-20.

Bergeron, B. (2002). Essentials of shared services. New York: John Wiley \& Sons.

Kislingerová, E. (2008). Inovation of economic tools and organization management. Praha: C. H. Beck.

Kučerová, I. (2016). Europeinization of central European countries. In International Conference on European Integration (pp. 526-536). Ostrava: VŠB-TU, Faculty of Economics.

Maatman, M., \& Meijering, J. (2017). Why sharing is synergy: The role of decentralized control mechanisms and centralized HR capablities in creating HR shared service value. Personnel Review, 46(7), 1297-1317.

Rothwell, A. T., Herber, I. P., \& Seal, W. (2011). Shared service centres and professional employability. Journal of Vocational Behaviour, 79, 241-252.

Skorková, Z., \& Tarišková, N. (2017). Buseness service centres in Slovakia and their current chllenges. Slovenská Akadémia Manažmentu, 5, 1-8.

Slusarczyk, B. (2017). Shared service centres in central and Eastern Europe: The example of Poland and Slovakia. Economics and Sociology, 10, 46-58.

Tammel, K. (2017). Shared services and cost reduction motive in the public sector. International Journal in Public Administration, 40(9), 792-804. 